\title{
(The Impossibility of) Acting Upon a Story That We Can Believe
}

\author{
Zoltán Bodizsár Simon
}

\author{
This is a draft version \\ For free access eprints (of limited number) follow the link to
}

Rethinking History 22:1 (2018)

\begin{abstract}
The historical sensibility of Western modernity is best captured by the phrase "acting upon a story that we can believe." Whereas the most famous stories of historians facilitated nationbuilding processes, philosophers of history told the largest possible story to act upon: history itself. When the rise of an overwhelming postwar skepticism about the modern idea of history discredited the entire enterprise, the historical sensibility of "acting upon a story that we can believe" fell apart to its constituents: action, story form, and belief in a feasible future outcome. Its constituent parts are nevertheless still hold, either separately or in paired arrangements. First, believable stories are still told, but without an equally believable future outcome to facilitate. Second, in the shape of what I call the prospect of unprecedented change, there still is a feasible vision of a future (in prospects of technology and the Anthropocene), but it defies story form. And third, it is even possible to upon that feasible future, but such action aims at avoiding worst case scenarios instead of facilitating best outcomes. These are, I believe, features of an emerging postwar historical sensibility that the theory and philosophy of history is yet to understand.
\end{abstract}

\section{Keywords}

Unprecedented change; anthropogenic existential risk; humanity; acting upon a story; historical sensibility 


\section{Acting Upon a Story That We Can Believe}

Acting upon a story that we can believe - I cannot think of a phrase that better captures the modern historical sensibility. For histories were not merely told throughout Western modernity. To a large extent, although not exclusively, they have been told and written in order to facilitate the desired full realization of what they were about: nations, human emancipation, or modernity itself as a process of modernization. Yet, by introducing the phrase, I do not intend to describe a currently dominant form of societal appeal to history. What I hope to adequately name instead is a certain sense of historicity that Western societies are about to abandon by increasingly appealing to another that is emerging in the broadly understood post-Second World War period (stretching until now). This new historical sensibility attests today to the impossibility of holding together the constituents of the modern one: action, story form, and belief in a feasible future outcome.

The phrase "acting upon a story that we can believe" attempts to provide a conceptual understanding of both senses of historicity in their relation to each other. Accordingly, the plausibility and the significance of describing the modern Western appeal to history as feasible stories to act upon derives partly from an examination of its postwar disintegration. Most of the coming pages will attempt to carry out this work. There are, however, good reasons to consider the modern historical sensibility as "acting upon a story that we can believe" on its own right too. Hence, before beginning to argue for its disintegration, I would like to illuminate the sense in which acting upon believable stories defined the sense of historicity of the modern Western world.

To begin with a terminological clarification, by "historical sensibility" and "sense of historicity" I do not mean an actual sensation of history. I rather mean a mode of sensemaking, a distinctively "historical" mode of conceiving of ourselves and the world as changing over time. It can take the shape of a conscious activity, an implied attitude, or a non-reflexive way of relating to the world and things of the world upon which we do not necessarily reflect. Unlike the terms "historical thinking" and "historical consciousness" which imply self-awareness and refer to a deliberate engagement, "historical sensibility" as used here refers to a more general and all-encompassing mode of apprehending and appropriating ourselves and the world which may happen even in unconscious ways. Professionalized and institutionalized historiography is only one representative of such a historical sensibility, although probably the most powerful one. Together with philosophy of history, it is jointly responsible for the modern invention and dissemination of the agenda of acting upon a believable story as the story of history itself. 
Talking about the modern invention of history is in harmony with the most excellent scholarship of Reinhart Koselleck on the birth of the temporalized concept of history in the period between the mid-eighteenth and the mid-nineteenth century. According to Koselleck (2004, 194), "one of the conceptual achievements of the philosophy of the Enlightenment was enhancing history into a general concept which became the condition of possible experience and possible expectation." Prior to this, in the Christian worldview, "there was no history for which humanity might have been the subject or which could be thought of as its own subject" (Koselleck 2004, 194). Although Koselleck emphasizes the extent to which such a unitary concept of history brought together individual histories in a collective singular, it seems to me the most momentous aspect of this conceptual innovation lies elsewhere, namely, in rendering change for the better in human affairs possible. Whereas the Christian worldview granted the possibility of change for the better by divine intervention and as an entrance into another world, the late Enlightenment brought about the concept of history as future-oriented course, over which change in the world of human affairs plays out as executed by humans.

Koselleck, I think, tries to capture this aspect by referring to the "makeability" of history. Once the future opened up and change for the better in human affairs became a possibility as the course of history, that possible change became prone to facilitation. Koselleck $(2004,197)$ attributes the establishment of the makeability of history to Kant by claiming that Kant attempted to translate "the latent natural plan, which seemed set to force humanity onto the course of unlimited progress, into a conscious plan of rationally endowed man." Intentions and results obviously diverged whenever it came to actual attempts to make history. Although Koselleck also explores this divergence, I do not wish to follow his investigations further, as the point I want to make concerns only the establishment of the possibility of making history by acting upon an already assumed course of affairs.

Besides the affiliation with Koselleck's study, what I label as providing feasible stories for future action is also somewhat close to what Jörn Rüsen (2005) elevates into being one of the five principles of modern historical thinking in his disciplinary matrix: temporal orientation. The entire matrix, with its focus on not only narrative form but also on methodological rules, is designed to be an interpretation of historical studies. But the story form and what Rüsen considers to be the orienting function seems to be shared by historiography with other practices relying on the very same historical sensibility. For one thing, philosophies of history most certainly did not share the methodological rules of empirical research (one of Rüsen's principles) with historical studies. Yet, just like historiography according to Rüsen, they provided a practical story to orient and act upon. In 
the recent interpretation David Carr $(2014,140)$ this means that although philosophies of history often used "the language of prediction and even prophesy," they were "expressing a practical attitude toward the future and participating, through their language and their concepts, in an effort to move history in a certain direction." What is more, Carr $(2014,140)$ even states that such "an attitude toward history" is something that "in the modern world" we all "share to some extent, whether we are philosopher or not."

Although I have serious reservation about Carr's overall phenomenological approach to history, I think that he is right about the modern practical attitude. But history itself, with the central character humanity, is only the largest possible story to act upon, typically by philosophies of history. It is still an open question whether professionalized historical studies can reasonably be said to exhibit a similar attitude when telling their smaller scale stories. Considering nineteenth-century historiographies of nation which themselves facilitated nation-building by writing its story (Berger with Conrad 2015), the answer is rather obviously affirmative. Especially in the case of romantic historiography and its main representative, Jules Michelet, who explicitly took pride midwifing the birth of the French nation (Cf. Kogan 2006; Gossman 1990). A possible counterargument could nevertheless point out that the institutionalization and the professionalization of historical studies in the same century took place as accompanied by claims concerning the scientific character of the discipline. Such an objection would argue that historians themselves oftentimes claimed to study the past for its own sake and conduct a disinterested study by appeals to objectivity.

By addressing this hypothetical objection, it is crucial to make clear how this selfdescription and self-conception of the discipline of history in the time of its institutionalization has already been refuted by histories of historiography in the last halfcentury. It is not merely an accident that Rüsen, as mentioned above, attributes the orienting function to the discipline as such, disregarding appeals to disinterestedness. Similarly, Lorenz (2008) has shown how historiography could never "draw the line" between their claims to be scientific on the one hand their actual involvement in providing practical orientation (mostly by creating the aforementioned national myths). But the self-image of scientific historiography was advocated strongly enough to convince contemporaries of the institutionalization. Even Nietzsche (1980) gave in to it and expressed his contempt for the type of history which studies the past for its own sake by labelling it "antiquarian." Yet, in the judgement of today's history of historiography - as represented here by Iggers (2002, 236) - "Nietzsche did not understand the extent to which this call for history to become a detached science was ignored, and that history rather was used for very practical aims which lacked a scientific basis." Finally, as I argued elsewhere (Simon 2015), even today's calls for 
an engagement with practical past (White 2014) or for a return to long-term historical interpretations to guide the future (Guldi and Armitage 2014) are, in fact, reminders of what the academic discipline of history stood for since its early days.

All in all, recent work both in the theory of history and the history of historiography supports very well an interpretation of the modern historical sensibility as "acting upon a story that we can believe." Regardless of whether philosophies of history or academic histories tell it, such a feasible story to act upon assumes a deep continuity over time underlying all changes in the condition of the storied subject. Whereas philosophies of history typically feature humanity as the protagonist of their plot, particular histories can in principle be concerned with the development of practically anything. The endpoint of the story, even if it is not recounted explicitly, is in a future outcome and future fulfillment as indicated or foreshadowed by the already outlined development of past and present states of affairs. In return, the future outcome appears as feasible precisely because there is a developmental story pointing toward its direction. There certainly is a circularity involved in how a desired future outcome reinforces a story and how, at the same time, the story renders the desired future feasible and calls for action in order to achieve the future. The perfect example of such a circular reinforcement is the Marxist future of a communist society and the story about the route to get there.

But this is not to say that professional historical studies and modern philosophies of history deliberately called for societal action in order to make their advocated vision of the future true by telling a story. This is only to say the modern historical sensibility of "acting upon a story that we can believe" underlay historical studies and philosophies of history just as much as it underlay more explicit political engagement. As to the latter, communities established on stories told by utopian socialism, Comte's positivism based on an assumed law of historical development which inevitably leads to a scientific society, women's suffrage and emancipatory stories, ideas of technological progress and practices of industrialization, or today's modernization theories and efforts attest to the modern sense of historicity. Again, rather obviously, this does not mean that such historicity fully informed every instance of socio-political action or every piece of academic historiography ever produced. This means only that Western modernity gave rise to a concept of history which, according to Hannah Arendt $(1961,58)$, "became a man-made process, the only all-comprehending process which owed its existence exclusively to the human race."

It cannot be emphasized enough how history as (1) human-made and as (2) a process emerged as a specificity of the modern age, establishing the possibility of "acting upon the story that we can believe" and kicking off the abovementioned large variety of "historical" 
endeavors. Its emergence did not immediately dissipate all previous patterns of thoughts and modes of actions. Similarly, even if there is a novel kind of historical sensibility emerging, it will not make the modern one disappear right away. This is sense in which I will argue for the ongoing disintegration of the possibility to "act upon a story that we can believe." Even though Western societies can no longer hold together action, story form, and belief in a feasible future outcome in a single agenda, the constituents are still held either separately or in paired arrangements, tailored to current socio-cultural concerns. On the coming pages, I will sketch three of these dispositions as fundamental features of an emerging postwar historical sensibility that the philosophy of history is yet to explore and understand.

First, although it is still possible to tell believable stories, they are now without an equally feasible future outcome to facilitate. This arrangement concerns primarily the sociopolitical domain. Second, although there still are feasible vision of the future, they defy story form. Instead of appearing as results of gradual betterment, believable postwar visions of the future take the shape of unprecedented change, that is, a change that implies a complete disconnection from preceding past conditions. Such future prospects feature most prominently in the ecological and technological domains. Thirdly and finally, although it is even possible to act upon that believable future, the motivation for action no longer derives from a desired best outcome. Societal action today aims at avoiding worst prospects of unprecedented change which are characteristically dystopian and apocalyptic.

\section{Believable Stories without a Future}

The situation of feasible stories lacking an equally feasible future outcome can best be highlighted a dilemma. On the one hand, as is well known, that the postwar period brought about a widespread intellectual suspicion towards the idea of a historical process. Lyotard (1984, xxiv) famously condensed this suspicion into a definition of postmodern condition as "incredulity toward metanarratives," in which a metanarrative is distinguished by virtue of implying a philosophy of history to legitimize knowledge claims. On the other hand, the processual temporality of grand narratives survives to this day in conventional historical narratives. As Danto (1985, 1-16) argues, although philosophy of history and historiography are different in kind due to the different nature of their respective engagement with the future, the grandiosity of narratives of philosophy of history is only different in degree from narratives of historiography. Whereas philosophy of history told the story of the whole of history from an illegitimate "knowledge" of an assumed future outcome, historiography 
spares an engagement with the future. Otherwise, according to Danto (1985, 12), the former's "mode of organization, then, is indeed the historical mode of organization."

Danto's claim about the absence of historiography's engagement with the future is questionable. Especially concerning the modern sense of historicity and modern historiography with its paradigmatic involvement in nation-building processes, as reviewed in the previous section. Yet it may be right concerning the usual mode of historiography and the sense of historicity of Danto's own time, which is precisely what I will argue for. Before that argument, however, I would like to show how Danto's other claim about the formal similarity of philosophy of history and historiography is reinforced and even radicalized by Hayden White. In Metahistory, White (1973, ix) aims to show - among many other things that "there can be no 'proper history' which is not at the same time 'philosophy of history," the latter understood here in the classical sense. If White is right, then insofar as there is history as historical writing, there must be philosophy of history, and thus there must be ideas of a historical process around, at least as implied by historical studies. What this means is not only that historiography and the philosophy of history are of a formal unity, but also that they are interdependent.

The result is an overtly confused and paradoxical situation in which our current historical sensibility seems implicitly rely on an explicitly repudiated idea. Despite all suspicion and hostility towards history as process at the largest scale, there is a sustained demand for the socio-cultural practices informed by a processual, directional and developmental sense of historicity. How to make sense of all this? Is Western thought schizophrenic in both denying and engaging in the historical sensibility of "acting upon a story that we can believe"? Is it a double bind to get along with or a dilemma waiting to resolved?

The answer I wish to offer is that the simultaneity of the impossibility of the modern idea of history and its entailment in socio-cultural practices is indeed a dilemma - but one that cannot be resolved. The resolution of the dilemma would be to make a choice: either to drop the modern idea of history together with all its socio-cultural practices, or to fully commit to pursue both and thereby revive directional and developmental history together with the prospect of its supposed future fulfilment. It is only insofar as the dilemma remains unresolved - insofar as it remains a dilemma - that it brings about the disintegration of "acting upon a story that we can believe."

Hence the first element of the historical sensibility emerging in the post-Second World War times is the dilemma itself. Due to the sustained implicit engagement, it is still possible to tell directional and developmental stories; but due to the explicit disbelief in the overall 
idea of history involving a postulated future outcome, it is no longer possible to connect such stories to desired futures. As Danto's critique indicates, the incorporation of the postulated future outcome into a story to act upon was exactly what postwar hostility toward the idea of history targeted. With the vision of the future being collapsed after the world wars, and with the exercise of telling the largest possible story of humanity from the vantage point of that future vision being discredited, what remained are stories that end in the present and are told from a present point of view. In other words, the novelty of the postwar situation is not that grand narratives actually became discredited (they even gain popularity lately in various shapes from global to deep histories). The novelty of the situation is the absence of the future in the formal structure of stories deemed feasible. It has become difficult to tell stories in order to facilitate desired future outcomes, regardless of the grandiosity of stories.

This contention resonates more or less with recent cultural diagnoses, as advanced by Aleida Assmann (2013), Hans Ulrich Gumbrecht (2014) and François Hartog (2015). In their own respective ways, these diagnoses detect a transformation in the way Western societies configure a relationship between past, present, and future. Despite salient differences in accents and emphases, the diagnoses agree that a future-oriented modern configuration has been exchanged for a new arrangement. Whereas Assmann notes a disunity and disjoint in the current disposition of past, present, and future, Gumbrecht and Hartog talk about respectively - a broad or an extended present. Eventually, they all end up describing the historicity of our times as a prolonged investment in that which is already known and familiar by closing off the future.

These diagnoses may be highly relevant for my argument, even though they seem to capture only a piece of the larger picture. The limits of their scope call for two important qualifications. To begin with, theories of presentism introduce their turning point in the shape of decisive political events, such as the Fall of the Berlin Wall or the end of the Cold War. But change concerning long-standing patterns of thought and ways of conceiving of the world and ourselves does not belong to the world of political events. It is not merely an accident that Koselleck ties the conceptual shift that gave birth to the modern idea of history to an entire period covering about a century. Turning points in political history and turning periods in the realm of ideas should not be conflated. In light of this - and also the abovementioned post-Second World War hostility toward a future-entailed historical process - it seems more plausible to claim that change regarding the future-orientation of Western societies has emerged somewhat earlier than theories of presentism imply, and is still ongoing. 
Then, the second and closely related qualification concerns the political focus of cultural diagnoses. For it is in the explicitly political domain that believable stories are deprived of the possibility of acting upon them because the present appears as extended into the future. In fact, even Assmann, Gumbrecht, and Hartog do not think that Western societies are done with the future. They all note instead that it has become customary to talk about the future in catastrophic terms, especially with respect to climate change and technological innovations. These are, however, occasional remarks and not attempts at gaining a conceptual understanding of such newer future prospects. In the case of Gumbrecht this is hardly surprising. Gumbrecht (2015, xiv) openly concedes that "the electronic world, its rhythm and its form of communication, are repugnant" to him. What is more, Gumbrecht $(2015,64)$ even makes the not very flattering confession that whenever it comes even only to "electronic communication devices," "I try to know as little about them as I can possibly afford."

One could hardly ask for a better justification of the necessity to inquire a bit more thoroughly into recent future prospects. Especially in light of the fact that Gumbrecht is a major influence on Assmann, and his theory of the broad present parallels Hartog's ideas about an extended present. As insightful as cultural diagnoses are, in my view they do not pay sufficient attention to the future component, which brings me directly to the second and third elements of our postwar historical sensibility that I wish to introduce. For outside the political, a vision of the future reigns and even action is possible.

\section{Believable Future That Defies Story Form}

Although feasible stories Western societies tell today are lacking an equally feasible future to facilitate by societal action, the future itself is not lost. What became unfeasible is a vision of the future that could be connected back to the past to conceive of it as a single unfolding story. Today, it is increasingly replaced by a specifically postwar vision of the future in the Western world that I came to call unprecedented change (Simon 2015; 2017; 2018). From nuclear warfare to the ecological prospects of anthropogenic climate change, Western societies envision today future scenarios which cannot simply be configured as gradually developing out of preceding states of affairs. Yet the unprecedentedness of postwar prospects is nowhere more apparent than in technological visions, which gained new life after the initial boom and the birth of artificial intelligence research and cybernetics in the 1950's (see Hayles 1999). Bioengineering, nanotechnology, various brands of transhumanism, artificial 
intelligence, the merging of human and the machine, or mind uploading promises today the complete alteration of the human condition as we know it.

When I first introduced the notion of unprecedented change on the occasion of discussing the Anthropocene (Simon 2015), my initial hope was that inquiring into the historical sensibility that can be traced in the future vision of unprecedented change will result in a very different but nevertheless believable story to act upon. I thought that a concept of history fitting to the future vision of unprecedented change will simply invent a story form other than the developmental one that characterized the modern concept of history. But the more time I spent on the issue, and the more time I spent especially on the future vision of technology (Simon 2018), the more pressing it became to recognize that the future vision of unprecedented change simply defies story form.

But how exactly does this happen? How can visions of the future resist efforts to mold them into story form? To answer this question, the work of historians and theorists of history is of limited assistance. True enough, the ecological vision and the notion of the Anthropocene have already had an impact on historical thinking and begun to gain a quickly accelerating attention after the eye-opener engagement of Dipesh Chakrabarty (2009), ${ }^{1}$ to which I will come back later. But the heavily related technological vision and the potentially even greater consequences of the prospect of a posthuman / transhuman future for our historical sensibility are yet to be explored. Ewa Domanska and Antonis Liakos have nevertheless already devoted attention the issue. As for Domanska's engagement with posthumanism, her main focus lies in the divide between human and non-human with respect to material objects and animals (Domanska 2006; 2010; 2017). Such understanding of posthumanism is linked to a discourse within the disciplines still known as humanities and social sciences. It connects to a theoretical critique of humanism, anthropocentrism and speciesism that Cary Wolfe reviews in the book What is Posthumanism?. The challenge that such critical posthumanism wishes to meet is, according to Wolfe $(2010,62)$, "the challenge of sharing the planet with nonhuman subjects and treating them justly."

Critical posthumanism is nevertheless not the only game in town, and for the fate of historical sensibility today it is not even the most important. I think that the emerging novel sense of historicity has less to do with such posthumanism as a genealogy of philosophical criticism fueled (and bounded) by the imagination of humanities scholarship, and more to do with the imagination of scientific laboratories. The posthumanism that directly matters for Western historical sensibility is the posthumanist / transhumanist vision of technology, focusing on beings envisioned as literally post human. Technological posthumanism is not concerned with describing already existing non-human inhabitants of the planet as fellows 
to humans. Instead, it invests in the prospect of bringing about not-yet-existing non-human beings in various ways, from enhanced beings escaping human confines to the expected creation of greater-than-human machine intelligence. Differently put, technological posthumanism envisions the emergence of an era of posthumanity (a prospect about which critical posthumanism is, needless to say, critical).

The expectation of such an epochal transformation is an unmistakable manifestation of a sense of historicity. But the amount of reflection it has gathered so far cannot compare to already widespread discussions on the Anthropocene (as another evidently "historical" marker). Accordingly, when explicitly addressing the question of how this technological vision challenges what we think about history, the best conversation partner Liakos finds is a tradition of "end of history" theories and not contemporary historical theorists. Maybe this why Liakos seems to be concerned with bringing such prospects together with history as we know it, without considering the possibility that newer prospects exhibit a sense of historicity in their own.

The suggestion of Liakos $(2013,69-70)$ is that we should attribute a role to historiography as "the discipline of traversing thresholds / boundaries between the human and the non-human," and conceive of the human "as crafted in society." What this means is that Liakos retroactively redefines the notion of history as if it has always included today's concerns in older shapes. If history already conceives of humans "as crafted in society," there is no need to be concerned about what biotechnology advocates today because it no longer appears as a radical intervention. And if history is "the discipline of traversing threshold / boundaries between the human and the non-human," then somewhat naturally it already understands posthumanism.

The take-away message of such operations is that there is nothing to worry about, there is not much challenge here, historical thinking as we know it is more useful than ever, so we can just carry on. Needless to say, this is actually the modern historical sensibility put to work and exercised on the challenges posed to itself. It assumes that the new is a newer version of the old, that today's technological engineering of humans is just another grade in history as the development of humans always being crafted in society. And all this even makes perfect sense in a certain way. For much of the postwar technological visions of the future tell the same story about their own deep past, as if their newer concerns were just an improvement on already familiar old concerns. Scholars of posthumanism sometimes tell stories about how humans were always already posthuman (Ferrando 2016), and even transhumanism tells a legitimizing story in which it appears to be consistent with the Enlightenment vision of the perfectibility of human beings. This is the ground on which 
Nick Bostrom $(2005,2)$, the probably most prominent transhumanist philosopher today, claims that "transhumanism has its roots in rational humanism."

Mobilizing the modern sense of historicity in making sense of posthumanity, however, does not yield to fruitful results. It simply gives in to the self-conception of the advocates of technological prospects, which is not a particularly useful analytical strategy. ${ }^{2}$ In fact, the most interesting aspect of today's technological visions is the contradiction between legitimizing stories and explicit aims. For "The Transhumanist Declaration," which features as an appendix to Bostrom's article, clearly goes beyond what can reasonably termed as improvement upon an already assumed human potential. Consider its opening sentences:

Humanity will be radically changed by technology in the future. We foresee the feasibility of redesigning the human condition, including such parameters as the inevitability of ageing, limitations on human and artificial intellects, unchosen psychology, suffering, and our confinement to the planet earth. (Bostrom 2005, 21)

No wonder that these words, together with assertions such as "we seek personal growth beyond our current biological limitations" (Bostrom 2005, 21), stir controversy. Although not as much about the potential of human enhancement as about the ethical question of how far should enhancement go, ${ }^{3}$ because the potential of the technological vision is clear. As Nicholas Agar $(2010,13)$, one of the main opponents of profound changes puts it: "radical enhancement is likely to create beings who do not belong to the human species."

The potential of bringing about non-human beings is at the heart of matter. It is the most apparent in the vision of the future of artificial intelligence as the creation of beings other-than-human with greater-than-human intelligence. "Technological singularity" is the term that intends to capture the event-like character of the anticipated change following the postulated success of creating superintelligence. The notion has been made popular by Vernor Vinge $(1993,12)$, claiming that "from the human point of view this change will be a throwing away of all the previous rules, perhaps in the blink of an eye, an exponential runaway beyond any hope of control." According the argument, is seems reasonable to assume that a greater-than-human intelligence would create beings of even greater intelligence in an exponential manner. Hence, when Vinge $(1993,14)$ asks the somewhat rhetorical question "And what happens a month or two (or a day or two) after that?," his answer is hardly surprising: "I have only analogies to point to: The rise of humankind. We will be in the Post-Human era." Such a new era as the ultimate prospect of technology is not simply about the birth of non-human beings. More importantly, it is about the birth of beings greatly outperforming and potentially superseding human beings, with all threats and dangers 
involved for the continued existence of human beings (Bostrom 2014). I will address these threats in more details in the next section. For now, keeping in mind these considerations, I would like to return to principal question of this section concerning how such prospects of unprecedented change defy story form.

The answer begins in a retrospective look at the modern concept of history. When classical philosophies of history authored the largest possible story to act upon, they typically featured humanity as their protagonist. Whatever changes occurred in their plot, the protagonist retained its self-identity while going through substantial character development. As mentioned earlier, there is no formal difference between grand narratives and more conventional historical narratives on a smaller scale. In order for a historical narrative to qualify as the history of $\mathrm{X}$, subject $\mathrm{X}$ needs to be identifiable as $\mathrm{X}$ at all stages of the narrative, despite any changes which occur to $\mathrm{X}$.

Narrative philosophies of history (White 1965; Dray 1971) refer to this self-identical $\mathrm{X}$ as the "central subject" of historical narratives. Invested with organizing and unifying functions, the "central subject is responsible for endowing narratives with integrity and comprehensibility. When prospects of unprecedented change envision to bring about a subject other-than-human or a non-human which potentially outperforms and supersedes the human subject, they threaten to eliminate the central subject of the story of history, thereby defying the possibility to fashion the narrative with integrity and comprehensibility. In other words, they fail to uphold a self-identical central subject around which a story could be structured and organized. For the future subject of the technological vision is not an altered subject of the past, but a completely another subject. Writing a history as a believable story to act upon requires connection and association between past and future states of affairs in terms of a common subject or character whose past and future is at stake. The prospect of unprecedented renders this connection and association impossible due to the lack of the common subject or character whose past and future could be at stake over the course of a story.

\section{Acting Upon a Fear of the Worst Future}

Although in the emerging historicity of Western societies the feasible stories cannot facilitate action due to the lack of an equally feasible political vision, and although the believable future of unprecedented change defies story form, action is still possible. As the previous section indicates, prospects of unprecedented change are either prospects of a complete alteration 
or even supersession of the human condition as we know it, which may appear as catastrophic and dystopian. As hardly anybody would wish to facilitate the "achievement" of catastrophic visions, it is evident that societal action upon such prospects has to be characteristically different from what the modern sense of historicity entailed.

The catastrophic character of the envisioned future is the most obvious in the case of nuclear warfare and the anticipated consequences of anthropogenic climate change. It may seem less obvious when it comes to technology, given that even bringing about greater-thanhuman intelligence may appear utopian insofar as such intelligence is controlled and created with the hope to benefit humanity. Nevertheless, even the seemingly shiniest prospect of a technological utopia is inherently dystopian, precisely because of the constant threat of losing control and also because of the threat posed by the fact that human reasoning is by definition unable to assess greater-than-human intelligence. This is what the notion of technological singularity describes and warns about (Vinge 1993). Regardless of whether technologically enhanced non-human beings are brought forth as a result of artificial intelligence research or human enhancement, they appear as a threat to the continuation of human life as we know it. Advocates of human enhancement are, of course, aware of the dystopian prospects inherent in their technological utopianism. "The Transhumanist Declaration" touches upon the threats and dangers necessarily entailed in their hopes, calling equally tragic "if the potential benefits failed to materialize because of technophobia and unnecessary prohibitions," and "if intelligent life went extinct because of some disaster or war involving advanced technologies" (Bostrom 2005, 21).

The threats and dangers of the technological vision, just as well as the threats posed by anthropogenic climate change, made their way lately into the consideration of the members of the Bulletin of the Atomic Scientist, which installed the Doomsday Clock in 1947 against the backdrop of nuclear threats. The symbolic function of the Clock is to convey a sense of how close human civilization is to potentially destroy itself. In 2017, it shows two and a half minutes to midnight, half a minute closer to the hour than in the previous report of the Bulletin, dating from 2015. It is nevertheless the 2015 report that I would like to quote somewhat lengthily fashion, because it wonderfully exhibits the language in which current debates on future prospects play out. Under the heading "Emerging Technology," the report proceeds as follows:

The fast pace of technological change makes it incumbent on world leaders to pay attention to the control of emerging science that could become a major threat to humanity. It is clear that advances in biotechnology; in artificial intelligence, particularly for use in robotic weapons; and in the cyber realm all have the potential to 
create global-scale risk. The Bulletin continues to be concerned about the lag between scientific advances in dual-use technologies and the ability of civil society to control them. The Science and Security Board now repeats the advice it gave last year: The international community needs to strengthen existing institutions that regulate emergent technologies and to create new forums for exploring potential risks and proposing potential controls on those areas of scientific and technological advance that have so far been subject to little if any societal oversight. (Annual Report 2015)

The language of "risks," and even more, the language of a "global-scale risk" that is a "threat" to the entire "humanity" which in turn demands "control" is not the language of scaremongers only. In human enhancement debates, both bioconservatives and advocates of transhumanism speak the same language of threats and risks, although they may disagree over what exactly qualifies as threat. Whereas "the most significant threat posed by contemporary biotechnology" for Francis Fukuyama $(2002,7)$ in the bioconservative camp is already the prospect that it may "alter human nature and thereby move us into a 'posthuman' stage of history," many transhumanists may regard this prospect as the ultimate object of their desire.

The difference of the various positions on what constitutes a threat and what is desired lies in dissenting views on what counts as "human." It is not merely an accident that the transhumanist Bostrom, in arguing that the threat we all face today is best described as "existential risk," defines the term in a way that avoids the mention of "human" for the sake of a wider category. According to the definition, "an existential risk is one that threatens the premature extinction of Earth-originating intelligent life or the permanent and drastic destruction of its potential for desirable future development" (Bostrom 2013, 15). This is not to say that "Earth-originating intelligent life" has never faced existential risks before. It has happened many times in the shape of what Bostrom calls natural existential risks (asteroid impacts, gamma-ray bursts, and so on). What is new according to Bostrom $(2013,6)$ is that "the great bulk of existential risk in the foreseeable future consists of anthropogenic existential risks." The main anthropogenic existential risks we face today are precisely the ones that feature in the consideration of the members of the Bulletin of the Atomic Scientist in setting the Doomsday Clock: nuclear warfare, climate change and technology. Besides, they are also the ones that I call as prospects of unprecedented change.

The point I would like to make by reciting both Bostrom and the Bulletin report is that the specific threat that emerged in the discourse of postwar Western societies is extinction by human-induced activity. For the sake of simplicity, I will refer to human extinction, leaving the room open for all dissenting views on what counts as "human." There are two essential and heavily interrelated features of this emerging discourse on threats to 
humanity that I wish to pay special attention to. The first is that the new discourse emerged outside the humanities and social sciences. The second is that it correspondingly speaks about human beings and humanity not as a cultural but as a biological-existential category, or at best as a category that renegotiates the cultural / biological divide (notwithstanding the fact that from the standard perspective of the interpretive humanities of the last decades, a discourse on humanity as a biological category is itself a cultural artifact).

As to emergence of new discourse on humanity outside the humanities, it is evident in the case of the scientific-technological prospect of biotechnology, artificial intelligence, and human enhancement. The ecological prospect of anthropogenic climate change is a more complex case, given the extremely quick appropriation of the notion of the Anthropocene by the most humanities disciplines. Despite the fact that the officially yet unapproved term came into circulation as a geological epoch-marker (Crutzen 2002), the humanities have already transformed it into signaling a new socio-cultural era. This, I believe, resulted in the creation of a humanities literature on the Anthropocene which parallels the natural scientific discourse, but without much effort to understand it (see Simon 2017). For the challenge that the humanities in general and historical studies in particular face today lies precisely in the extent to which such newer ecological and technological prospects do not fit very well with the age-old, routinized and accustomed conceptual tools of the humanities.

This leads straight to the second aspect. Nowhere is the unfit between the scientific and the humanities discourse more palpable than in the new universalism of the human of the Anthropocene and the (post)human of scientific-technological visions as measured against the old universalism of the humanities. As to the latter, humanity in the discourse of modern humanities has been the central subject of a unitary historical process. But this notion came under heavy criticism in the last half-century within humanities scholarship itself. Today, the common attitude toward this old universalism is to note its inherent Eurocentrism and its inattentiveness to inequalities in the social world. In light of take-away message of the previous section, all this is nothing surprising. With the idea of a historical process becoming unfeasible in the postwar period, a universal humanity as the central subject of the very historical process simply had to become unfeasible too. Complications arise when the standard humanities criticism of old universalism is applied to the new universalism of prospects of unprecedented change. For an existentially threatened humanity understood as a species which is part of an even greater universalism of "Earth-originating intelligent life" may be something completely other than a socio-politically evolving humanity over the course of history. 
The case of the Anthropocene is the most illuminating in this respect. For a large part of humanities scholarship exhibits and attitude similar to Malm and Hornborg (2014) when presuming that talking about humanity necessarily means talking about socio-political human development, so that it seems necessary to point at intra-species inequalities and questions of responsibility. Nobody doubts that such questions are of utmost importance. The curious thing is that the attitude behind asking such indispensable questions is less of an actual engagement with the assumptions of current scientific literature and more of a projection of long-standing humanities concerns over that which otherwise is unfamiliar and unexplored. Contrary to this, Dipesh Chakrabarty's attitude of attempting to comprehend the novelty of the universalism in scientific discourses on humanity seems a more sophisticated and promising one. In his early engagement, Chakrabarty (2009) was already mindful of how the natural scientific understanding implies a universal notion of humanity. Yet, he seemed to think initially that the main difficulty lies in coming to terms with a universalism that he thought to have a lot to do with the one he already intended to dismantle through his previous work of postcolonial criticism.

Lately, however, in his Tanner Lectures, Chakrabarty (2015) has become more explicit about the difference between the notion of humanity featuring in current scientific discourses and the tradition of humanities. Being inspired by Agamben (1998), Chakrabarty attributes the concept of qoe (bare life) to this emerging discourse as opposed to bios (good life) and claims that "life, not humans, emerges as one of the main concerns of the literature on climate science," Chakrabarty $(2015,142)$. To conceptualize the difference, Chakrabarty makes a distinction between homocentric and zoecentric views of the world. Whereas the former applies to modern histories of humanity, the latter intends to capture the emerging understanding of the human in climate science as one of the fellow species of the planet. Chakrabarty associates the former with a notion of the human as socio-politically divided and describes it by the Latin homo, the latter features the Greek anthropos. According to Chakrabarty $(2015,157)$ - and contrary to the bulk of humanities criticism - the anthropos of the Anthropocene "has no moral value and does not signify any moral culpability."

Chakrabarty's engagement with present-day challenges to the Western sense of historicity is, I think, the most inspiring, insightful and elaborate in historical studies. It may even be congruent with critical posthumanism as discussed earlier. But its usefulness is confined to ecological concerns. From the viewpoint of a theoretical investigation into a larger sense of historicity behind the entire discourse on existential threats (of which anthropogenic climate change is only an instance), the concept of zoecentrism as focused on biological species both human and non-human seems less instrumental when it comes to the 
technological vision. The most pressing theoretical task would be to conceptualize that which is common in the understanding of the human and humanity to the ecological and technological discourses, against the backdrop of that which is common to the modern historical understanding. I do not wish to pretend to have an answer right away to the not particularly modest questions implied by this task. Nor do I want to criticize Chakrabarty for not having such a comprehensive answer either. What I want to point out is only that coming to grips with this question of what is common to all discourses on threats to humanity is one of the most pressing tasks to face in trying to comprehend an emerging historical sensibility.

To connect all this back to the theme of this section on the possibility of acting upon feasible future prospects, it is in the context of threats to a yet-to-be-understood subject that I would like to offer my final contention. When facing the vision of unprecedented change in terms of extinction, societal action no longer takes the shape of achievement. Western societies no longer call for action in order to achieve the best of all prospects; instead, the principal aim is now to avoid the future that is the worst of all. This is what motivates climate change summits, treaties on nuclear weapons, and debates on introducing controlling mechanisms and safety checks on technological innovations. Action upon a future vision is still possible, but the paradigmatic from of action is mitigation and aversion. Whereas utopian futures brought about stories of potential fulfillment as an incentive to act for a desired outcome, postwar visions of unprecedented change imagine worst case scenarios of potential human (?) extinction events as an incentive to act against.

\section{Being Historical Today}

All these, I believe, are among the fundamental features of a postwar historical sensibility. To avoid potential misunderstandings, in place of a conclusion I would like to make clear that I do not wish to claim that such a postwar historical sensibility entirely replaced the one brought forth by the late Enlightenment. The latter one is still present in the longing of the Left for progressive politics or in transhumanist visions of human enhancement (insofar as enhancement is understood as improvement and is confined to a continuous betterment of an already assumed human potential). With the heyday of postmodernism gone, it is even possible to witness efforts which try to revive the modern sense of historicity in its most vigorous shape by advocating an engagement with the deep past to see where long-term developments steer humanity in the future. Besides recent calls for returning to "acting upon a story that we can believe" as mentioned earlier, the endeavor of big history is one of the 
most visible of such efforts. It tells what Hesketh (2014) calls the evolutionary epic, although in the shape of a history of the universe that happens to include human history. Then, even Chakrabarty $(2015,174)$ ends up retaining fully the modern sense of historicity by suggesting that "subordinating human history to the geological and evolutionary histories of the planet" may be the ultimate way to come to terms with the challenge of Anthropocene. But this would mean telling the same developmental story of history with the central subject humanity, except that this time the whole of history would be of an even larger scale one and the central subject would be a zoecentric understanding of humanity.

Finally, the effort of Eelco Runia (2014) to provide a philosophy of history in the classical sense can be an example taken from the narrowly understood field of the theory and philosophy. At its most inspiring, Runia's work defy the historical sensibility inherited from the Enlightenment by postulating a discontinuity-driven mechanism of history. At its more conventional, however, Runia's philosophy of history still recourses to old patterns of thought by stretching the developmental continuity of a cultural evolutionary pattern over a mechanism of discontinuous change. Although far more examples could be mentioned, it is not my intention to provide a full list of the practices in which the modern idea of history survives even in the twenty-first century. What I wish to show is only the survival itself, and that two senses of historicity co-exist today, regardless of the moral judgement I would pass on any of them.

My claim in this essay is confined to the novel one, emerging out of the most pressing, urgent and dominant concerns of our own time, conceived of as unprecedented change. With respect to such novel concerns all I can say is this: let's forget about recent efforts that aim at reviving the modern historical sensibility, about the deep continuity of evolutionary thinking, and about the notion of the practical past. Let's forget about the idea that these are still our best tools for coping with the issue human existence in general, and let's forget about the idea that these age-old conceptual tools are what historical writing needs in order to regain its public status in particular. In the twenty-first century, such efforts of revival are not vehicles of but obstacles to a theoretical understanding of our current condition. What the theory and philosophy of history needs is not a nostalgic longing for a vanishing history culture, but an understanding of the perhaps completely different way in which we already conceive of ourselves and the world "historically" today. 


\section{Notes}

1. From the viewpoint of this essay, historians' engagement with the Anthropocene fall into two categories. On the one hand, some historians ask the question of how their discipline may contribute to ongoing public discussion of climate change. This is the question asked by Guldi and Armitage (2014, 64-73). On the other hand, the more important and fruitful efforts follow Chakrabarty (2009) in asking the reverse question of what the Anthropocene demands from history. Although it makes sense to analytically differentiate between the two approaches, in practice they are often fused, such as in the treatment of Thomas (2014) or Chaplin (2017).

2. Critical posthumanism is of course skeptical about technological posthumanism. In the concise judgement of Rosi Braidotti (2016, 17), they "combine radical expectations of transhumanist enhancement, with a firm reiteration of enlightenment-based values such as rationality and liberal individualism. Apparently nonplussed by the internal contradiction of combining radical change with the perpetuation of tradition, they reject the critical edge of posthuman theory, appease venture capitalist interventions in fundamental research and strike a politically conservative note." Yet, it seems to me that the grounds for this skepticism is the rather uncritical acceptance of the self-narrative of technological posthumanism. Above, I repeatedly try to raise awareness of the fact that the radicality of technological posthumanism lies in its prospective aims which completely contradict to its self-narrative. When it comes to a comparative assessment of aims and prospects, I even think that the aim of critical posthumansim to extend emancipatory thinking over the non-human world by insisting on inherited conceptual tools (conceptual tools which have become textbook humanities criticism in the last decades) is far more conservative than the prospect of overcoming the human condition by the creation of literally posthuman beings. I nevertheless do not to intend this to be a value judgement as I find the conservativism of critical posthumanism indispensable in addressing the potential social inequalities so obviously entailed by technological prospects.

3. For an introductory overview of the many transhumanist and posthumanist positions about enhancement and biotechnology see Savulescu and Bostrom (2009); Sharon (2014); and Agar (2013). 


\section{References}

Agamben, Giorgio 1998. Homo Sacer: Sovereign Power and Bare Life. Stanford: Stanford University Press.

Agar, Nicholas 2010. Humanity's End: Why We Should Reject Radical Enhancement. Cambridge, MA: The MIT Press.

Agar, Nicholas. 2013. Truly Human Enhancement: A Philosophical Defense of Limits. Cambridge, MA: The MIT Press.

"Annual Report 2015 - Bulletin of the Atomic Scientist," 15. Available at: http://thebulletin.org/sites/default/files/Final-Annual-Report-2015.pdf (Accessed 3 December 2017)

Arendt, Hannah. 1961. Between Past and Future: Six Exercises in Political Thought. New York: The Viking Press.

Assmann, Aleida. 2013. Ist die Zeit aus den Fugen? Aufstieg und Fall des Zeitregimes der Moderne. München: Hanser.

Berger, Stefan with Christoph Conrad. 2015. The Past as History: National Identity and Historical Consciousness in Modern Europe. Basingstoke: Palgrave.

Bostrom, Nick 2005. "A History of Transhumanist Thought," Journal of Evolution and Technology, 14 (1): 1-25.

Bostrom, Nick 2013. "Existential Risk Prevention as Global Priority," Global Policy, 4 (1): 1531.

Bostrom, Nick. 2014. Superintelligence: Paths, Dangers, Strategies. Oxford: Oxford University Press. 
Braidotti, Rosi. 2016. "Posthuman Critical Theory," In Critical Posthumanism and Planetary Futures, edited by Debashish Banerji and Makarand R. Paranjape, 13-32. Springer India.

Carr, David. 2014. Experience and History: Phenomenological Perspective on the Historical World. Oxford: Oxford University Press.

Chakrabarty, Dipesh. 2009. "The Climate of History: Four Theses," Critical Inquiry, 35 (2): $197-222$.

Chakrabarty, Dipesh. 2015. The Human Condition in the Anthropocene. The Tanner Lectures in Human Values. Delivered at Yale University, February 18-19 2015. Available at https://tannerlectures.utah.edu/Chakrabarty\%20manuscript.pdf (Accessed 3 December 2017)

Chaplin, Joyce. E. 2017. "Can the Nonhuman Speak? Breaking the Chain of Being in the Anthropocene," Journal of the History of Ideas, 78 (4): 509-529.

Crutzen, Paul J. 2002. Geology of Mankind. Nature, 415: 23.

Danto, Arthur C. 1985. Narration and Knowledge: Including the Integral Text of Analytical Philosophy of History. New York: Columbia University Press.

Domanska, Ewa. 2006. "The Material Presence of the Past.” History and Theory, 45 (3): 337348.

Domanska, Ewa. 2010. "Beyond Anthropocentrism in Historical Studies," Historein, 10: 118130.

Domanska, Ewa. 2017. “Animal History,” History and Theory, 56 (2): 265-285.

Dray, William. 1971. "On the Nature and Role of Narrative in Historiography," History and Theory, 10 (2): 153-171. 
Ferrando, Francesca. 2016. "Humans Have Always Been Posthuman: A Spiritual Genealogy of Posthumanism," In Critical Posthumanism and Planetary Futures, edited by Debashish Banerji and Makarand R. Paranjape, 243-256. Springer India.

Fukuyama, Francis 2002. Our Posthuman Future: Consequences of the Biotechnology Revolution. New York: Farrar, Straus and Giroux.

Gossman, Lionel. 1990. “Jules Michelet and Romantic Historiography,” In Lionel Gossman, Between History and Literature, 152-200. Cambridge, MA: Harvard University Press.

Guldi, Jo and David Armitage. 2014. The History Manifesto. Cambridge: Cambridge University Press.

Gumbrecht, Hans Ulrich. 2014. Our Broad Present: Time and Contemporary Culture. New York: Columbia University Press.

Hartog, François. 2015. Regimes of Historicity: Presentism and Experiences of Time. New York: Columbia University Press.

Hayles, N. Katherine. 1999. How We Became Posthuman: Virtual Bodies in Cybernetics, Literature, and Informatics. Chicago: University of Chicago Press.

Hesketh, Ian. 2014. “The Story of Big History,” History of the Present, 4 (2): 171-202

Iggers, Georg G. 2002. "The Professionalization of Historical Studies and the Guiding Assumptions of Modern Historical Thought," In A Companion to Western Historical Thought, edited by Lloyd Kramer and Sarah Maza, 225-242. Malden, MA: Blackwell.

Kogan, Vivian. 2006. The "I" of History: Self-Fashioning and National Consciousness in Jules Michelet. Chapel Hill: University of North Carolina Press.

Koselleck, Reinhart. 2004. Futures Past: On the Semantics of Historical Time. trans. K. Tribe. New York: Columbia University Press. 
Liakos, Antonis 2013. "The End of History as the Liminality of the Human Condition: From Kojève to Agamben," In Crafting Humans: From Genesis to Eugenics and Beyond, edited by Marius Turda, 63-70. Goettingen: V\&R Unipress.

Lorenz, Chris. 2008. 'Drawing the Line: 'Scientific' History between Myth-making and Myth-breaking," In Narrating the Nation: Representations in History, Media and the Arts, edited by Stefan Berger, Linas Eriksonas and Andrew Mycock, 35-55. Oxford and New York: Berghahn.

Lyotard, Jean-François. 1984. The Postmodern Condition: A Report on Knowledge. Trans. Bennington, Geoff and Brian Massumi. Manchester: Manchester University Press.

Malm, Andreas and Alf Hornborg. 2014. "The Geology of Mankind? A Critique of the Anthropocene Narrative," The Anthropocene Review, 1 (1): 62-69.

Nietzsche, Friedrich. 1980. On the Advantage and Disadvantage of History for Life. Trans. Peter Preuss. Indianapolis: Hackett.

Runia, Eelco 2014. Moved by the Past: Discontinuity and Historical Mutation. New York: Columbia University Press.

Rüsen, Jörn. 2005. History: Narration - Interpretation - Orientation. New York: Berghahn.

Savulescu, Julian and Nick Bostrom, eds. 2009. Human Enbancement. Oxford: Oxford University Press.

Sharon, Tamar. 2014. Human Nature in an Age of Biotechnology: The Case for Mediated Posthumanism. Dordrecht: Springer.

Simon, Zoltán Boldizsár. 2015. "History Manifested: Making Sense of Unprecedented Change.” European Review of History, 22 (5): 819-834.

Simon, Zoltán Boldizsár. 2017. "Why the Anthropocene Has No History: Facing the Unprecedented," The Anthropocene Review, 4 (3): 239-245. 
Simon, Zoltán Boldizsár. 2018. "History Begins in the Future: On Historical Sensibility in the Age of Technology." In The Ethos of History: Time and Responsibility, edited by Helgesson, Stefan and Jayne Svenungsson, New York and Oxford: Berghahn. (forthcoming)

Thomas, Julia Adeney 2014. "History and Biology in the Anthropocene: Problems of Scale, Problems of Value." American Historical Review, 119 (5): 1587-1607

Vinge, Vernor. 1993. "The Coming Technological Singularity: How to Survive in the PostHuman Era," In Vision-21: Interdisciplinary Science and Engineering in the Era of Cyberspace, Proceedings of a symposium cosponsored by the NASA Lewis Research Center and the Ohio Aerospace Institute, Westlake, Ohio, March 30-31, 11-22. Available at: https://ntrs.nasa.gov/archive/nasa/casi.ntrs.nasa.gov/19940022855.pdf (Accessed 3 December 2017)

White, Morton. 1965. Foundations of Historical Knowledge. New York: Harper \& Row.

White, Hayden 1973. Metahistory: The Historical Imagination in Nineteenth-Century Europe. Baltimore: Johns Hopkins University Press.

White, Hayden. 2014. The Practical Past. Evanston: Northwestern University Press.

Wolfe, Cary 2010. What is Posthumanism? Minneapolis: University of Minnesota Press. 